\title{
Antitumour 2-(4-aminophenyl)benzothiazoles generate DNA adducts in sensitive tumour cells in vitro and in vivo
}

\author{
C-O Leong', M Gaskell', EA Martin², RT Heydon², PB Farmer², MC Bibby ${ }^{3}$, PA Cooper ${ }^{3}$, JA Double ${ }^{3}$, \\ TD Bradshaw*,' and MFG Stevens'
}

'School of Pharmaceutical Sciences, University of Nottingham, Nottingham NG7 2RD, UK; ${ }^{2}$ Biocentre, University of Leicester, Leicester LEI 7RH, UK; ${ }^{3}$ Cancer Research Unit, School of Life Sciences, University of Bradford, Bradford BD7 IDP, UK

\begin{abstract}
2-(4-Aminophenyl)benzothiazoles represent a potent and highly selective class of antitumour agent. In vitro, sensitive carcinoma cells deplete 2-(4-aminophenyl)benzothiazoles from nutrient media; cytochrome P450 IAI activity, critical for execution of antitumour activity, and protein expression are powerfully induced. 2-(4-Amino-3-methylphenyl)benzothiazole-derived covalent binding to cytochrome P450 IA I is reduced by glutathione, suggesting I A I-dependent production of a reactive electrophilic species. In vitro, 2 (4-aminophenyl)benzothiazole-generated DNA adducts form in sensitive tumour cells only. At concentrations $>100 \mathrm{nM}$, adducts were detected in DNA of MCF-7 cells treated with 2-(4-amino-3-methylphenyl)-5-fluorobenzothiazole (5F 203). 5F 203 (I $\mu \mathrm{M}$ ) led to the formation of one major and a number of minor adducts. However, treatment of cells with $10 \mu \mathrm{M} 5 \mathrm{~F} 203$ resulted in the emergence of a new dominant adduct. Adducts accumulated steadily within DNA of MCF-7 cells exposed to I $\mu$ M $5 F 203$ between 2 and $24 \mathrm{~h}$. Concentrations of the lysylamide prodrug of 5F 203 (Phortress) $\geq 100 \mathrm{nM}$ generated adducts in the DNA of sensitive MCF7 and IGROV-I ovarian cells. At I $\mu \mathrm{M}$, one major Phortress-derived DNA adduct was detected in these two sensitive phenotypes; $10 \mu \mathrm{M}$ Phortress led to the emergence of an additional major adduct detected in the DNA of MCF-7 cells. Inherently resistant MDAMB-435 breast carcinoma cells incurred no DNA damage upon exposure to Phortress ( $\leqslant 10 \mu \mathrm{M}, 24 \mathrm{~h}$ ). In vivo, DNA adducts accumulated within sensitive ovarian IGROV-I and breast MCF-7 xenografts $24 \mathrm{~h}$ after treatment of mice with Phortress $\left(20 \mathrm{mg} \mathrm{kg}^{-1}\right)$. Moreover, Phortress-derived DNA adduct generation distinguished sensitive MCF-7 tumours from inherently resistant MDA-MB-435 xenografts implanted in opposite flanks of the same mouse.
\end{abstract}

British Journal of Cancer (2003) 88, 470-477. doi:I0.1038/sj.bjc.66007I9 www.bjcancer.com

(c) 2003 Cancer Research UK

Keywords: 2-(4-aminophenyl)benzothiazole; Phortress; breast cancer; ovarian cancer; DNA adducts

Novel 2-(4-aminophenyl)benzothiazoles possess remarkably selective antitumour properties (Shi et al, 1996; Bradshaw et al, 1998a, b) and represent a mechanistic class distinct from clinically used chemotherapeutic agents. Consistently, these molecules are exquisitely potent $\left(\mathrm{GI}_{50}<10 \mathrm{nM}\right.$; $\mathrm{GI}$ is the drug concentration that inhibits cell growth by $50 \%$ ) against a specific subset of human cancer cell lines in the National Cancer Institute (NCI) in vitro anticancer drug screen, producing highly characteristic mean graph patterns.

2-(4-Amino-3-methylphenyl)benzothiazole (DF 203, NSC 674495) and 2-(4-amino-3-methylphenyl)-5-fluorobenzothiazole (5F 203, NSC 703786) are efficiently sequestered by sensitive cell lines (e.g. breast MCF-7, MDA-468; renal TK-10) (Chua et al, 1999a, b; Kashiyama et al, 1999). In stark contrast, insensitive cell lines $\left(\mathrm{GI}_{50}>10 \mu \mathrm{M}\right.$, e.g. breast MDA-MB-435; renal A498, CAKI-1; prostate $\mathrm{PC}-3$ ) fail to deplete these agents from nutrient media.

Planar, hydrophobic aminophenylbenzothiazole analogues are potent agonists for the aryl hydrocarbon receptor (AhR). Nuclear translocation follows high affinity (nM) binding $\mathrm{IC}_{50}$ between

*Correspondence: Dr TD Bradshaw; rcztb@unix.ccc.nottingham.ac.uk Received 12 July 2002; revised 23 October 2002; accepted 29 October 2002 ligand and cytosolic AhR. Xenobiotic response element (XRE)driven luciferase activity is induced and protein-DNA complexes are formed on the XRE sequence of the cytochrome P450 (CYP) 1A1 promoter (Loaiza-Perez et al, 2002). Thus, CYP1A1 mRNA activity and protein expression are induced exclusively in sensitive cell lines (Chua et al, 2000).

Crucially, induction of CYP1A1-catalysed biotransformation of 2-(4-aminophenyl)benzothiazoles within tumour cells is essential for drug activation. Covalent binding, detected between DF 203 and recombinant $\mathrm{CYP} 1 \mathrm{~A} 1$, requires metabolism and is significantly reduced by glutathione, suggesting the formation of an electrophilic, reactive intermediate species. Paradoxically, the C-6 hydroxylated biotransformation product, liberated into nutrient media of cells exposed to DF 203, is devoid of antitumour activity; moreover, this metabolite is able to antagonise cellular uptake of DF 203, covalent binding between CYP1A1 and DF 203, CYP1A1 activity and growth inhibition induced by DF 203 (Hutchinson et al, 2001).

Using $a b$ initio frontier molecular orbital (FMO) calculations, the presence or absence of exportable hydroxy metabolites of fluorinated 2-(4-amino-3-methylphenyl)benzothiazoles can be predicted (O'Brien et al, in press). Only the 5-fluoro isomer produced a conventional dose-response following treatment of cells; indeed, oxidative metabolism at C-6 was eradicated. 
Thus, 2-(4-amino-3-methylphenyl)-5-fluorobenzothiazole (5F 203, NSC 703786) is the favoured analogue for clinical consideration possessing enhanced efficacy in vitro and superior potency in vivo against human breast and ovarian tumour xenografts implanted in nude mice (Hutchinson et al, 2001; Bradshaw et al, 2002a). The lysylamide dihydrochloride salt of 5F 203 (Phortress, NSC 710305) has been derivatised at the exocyclic primary amine function fulfilling the criteria for a suitable prodrug. It is water soluble, chemically stable, pharmaceutically robust and undergoes rapid, quantitative bioreversion to the parent moiety in vitro and in vivo (Bradshaw et al, 2002a, b; Hutchinson et al, 2002) (Figure 1).

Additionally, a putative, as yet undefined, role of CYP1B1 in the mechanism of action of aminophenylbenzothiazoles has been implicated. CYP1B1 microsomes are able to metabolise DF 203, and modulation of CYP1B1 expression in sensitive cell lines has been observed in response to benzothiazole treatment as well as induction of CYP1B1 mRNA in MCF-7 cells. The CYPs comprise a superfamily of haemoproteins that catalyse the initial monooxygenation of a range of lipophilic endogenous, environmental or dietary xenobiotic substrates (Guengerich, 1992; Crofts et al, 1998). The substrate specificities of CYP1A1 and CYP1B1 overlap: both isoforms are important in the metabolism of polycyclic aromatic hydrocarbons (PAHs) and some heterocyclic amines (Shimada et al, 1996, 1998).

We have examined the hypothesis that exposure to analogues of this unique class of antitumour agent selectively generates benzothiazole-derived covalent DNA adducts in sensitive cell lines. The powerful ${ }^{32} \mathrm{P}$-postlabelling technique has been adopted for the detection of DNA adducts (Martin et al, 1997, 1998).

Optimisation of the procedure for detection and separation of benzothiazole-DNA adducts preceded in vitro studies to investigate time- and dose-dependent accumulation of 5F 203-DNA adducts in MCF-7 mammary carcinoma cells. 5F 203-derived adducts have been compared with DNA adduct formation in MCF7 and IGROV-1 ovarian carcinoma cells following treatment with Phortress. We demonstrate selective generation of adducts in the DNA of sensitive tumour cells in vitro and disclose chromatographically equivalent adduct formation in vivo in MCF-7 and IGROV-1 xenografts, following treatment of mice, i.p. with Phortress $\left(20 \mathrm{mg} \mathrm{kg}^{-1}\right)$.

\section{MATERIALS AND METHODS}

\section{Cell culture}

Human-derived carcinoma cell lines (MCF-7, MDA-MB-435 breast, HCT 116 colon and IGROV-1 ovarian) were cultured in RPMI-1640 medium supplemented with $10 \%$ FBS. Cells were subcultivated twice weekly to maintain logarithmic growth. Amines were prepared in DMSO as a $10 \mathrm{~mm}$ stock. Phortress was prepared in medium immediately prior to use. Cells were seeded at the appropriate density and, after $24 \mathrm{~h}$, nutrient media refreshed and drug introduced. Following the desired exposure period, cells were harvested by trypsinisation, washed in PBS and counted.

\section{In vivo procedure}

UKCCCR guidelines for the welfare of animals in experimental neoplasia were adhered to during all in vivo studies. MCF-7, MDAMB-435 breast and IGROV-1 ovarian xenografts were transplanted s.c. into flanks of NCR-Nu female nude mice. Animals were treated i.p. with $20 \mathrm{mg} \mathrm{kg}^{-1}$ Phortress $(n=4)$ or vehicle alone (saline). Pellets (60 day release $17 \beta$-estradiol, $0.72 \mathrm{mg} \mathrm{pellet}^{-1}$ : Innovative Research, USA) were implanted s.c. in mice bearing MCF-7 xenografts maintaining blood levels of $300-400 \mathrm{pg} \mathrm{ml}^{-1}$. Following $24 \mathrm{~h}$ exposure, tumours were removed and snap frozen $\left(-80^{\circ} \mathrm{C}\right)$. To examine the selective nature of DNA adduct formation in vivo, mice bearing MCF-7 and MDA-MB-435 tumours in opposite flanks were treated with Phortress. After $24 \mathrm{~h}$ treatment, animals were killed. Tumours were recovered and snap frozen.

\section{Determination of DNA adducts}

DNA was extracted from cells or xenograft tissue using Qiagen DNA extraction columns (Qiagen, Crawley, UK) as described in the manufacturer's instructions. DNA was dissolved in $0.5-1 \mathrm{ml}$ of $1: 100$ SSC $(0.015 \mathrm{M}$ sodium citrate, $0.15 \mathrm{M} \mathrm{NaCl}, \mathrm{pH} 7.2)$ and absorbance recorded at 230, 260, 280 and $320 \mathrm{~nm}$ using a UV spectrometer. The quantity of DNA was calculated from the absorbance at $260 \mathrm{~nm}$ assuming that an absorbance value of 1 is equivalent to a DNA concentration of $50 \mu \mathrm{g} \mathrm{ml}^{-1}$. The purity of the extracted DNA was determined from the $260 / 280 \mathrm{~nm}$ absorbance ratio. DNA with a ratio $>1.7$ was considered pure.
A

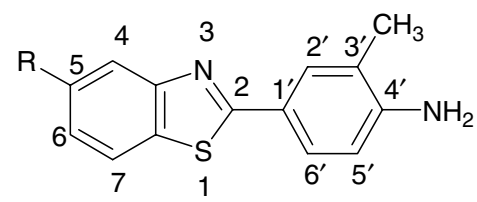

B<smiles>Cc1cc(-c2nc3cc(F)ccc3s2)ccc1NC(=O)[C@H](N)CN</smiles>

$2 \mathrm{HCl}$

Figure 2 TLC phosphorimager images of ${ }^{32}$ P-postlabelled DNA from MCF-7 (B and $\left.\mathbf{D}\right)$ and HCT I I6 (A and $\left.\mathbf{C}\right)$ cell lines, untreated $(\mathbf{A}$ and $\mathbf{B})$ and following exposure to DF 203 ( $1 \mu \mathrm{M} 72 \mathrm{~h}, \mathbf{C}$ and D).
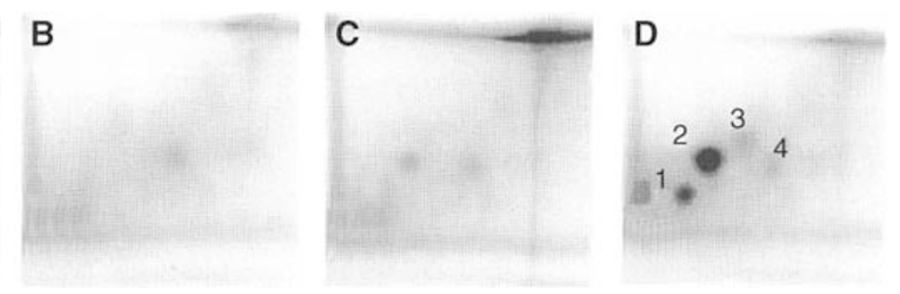

Figure I Structures of (A) 2-(4-amino-3-methylphenyl)benzothiazole (R=H; DF 203; NSC 674495), 2-(4-amino-3-methylphenyl)-5-fluorobenzothiazole $(R=F ; 5 F 203$, NSC 703786) and (B) the lysylamide dihydrochloride salt of 5F 203 (Phortress, NSC 7I0305).
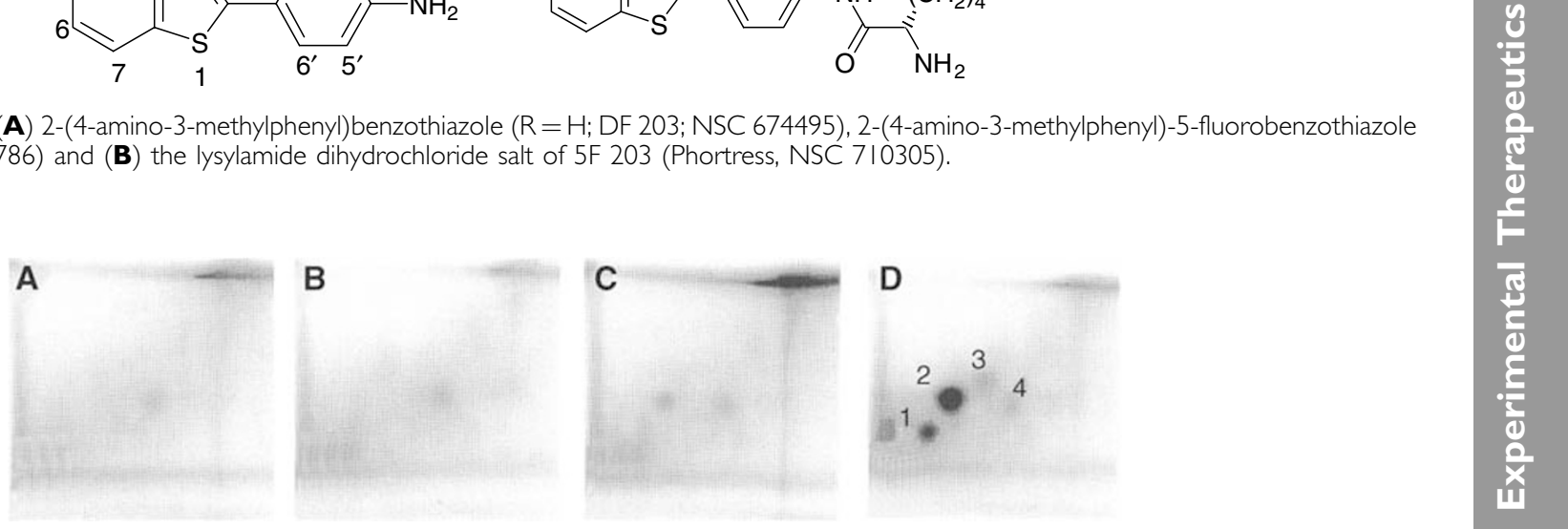
DNA was dried and hydrolysed to deoxynucleoside $3^{\prime}$-monophosphates by incubating $5 \mu \mathrm{g}$ of DNA with micrococcal nuclease $(175 \mathrm{mU})$, calf-spleen phosphodiesterase $(3 \mathrm{mU})$ in $1 \mu \mathrm{l}$ of SSCC (100 mM sodium succinate, $\mathrm{pH}$ 6.0: $50 \mathrm{~mm} \mathrm{CaCl}_{2}$ ) and $\mathrm{d}-\mathrm{H}_{2} \mathrm{O}$ to a total volume of $6.25 \mu \mathrm{l}$. The mixture was incubated at $37^{\circ} \mathrm{C}$ overnight.

Adducts were enriched by butanol extraction. Digested DNA $(5 \mu \mathrm{g})$ was diluted with $115 \mu \mathrm{l}$ HPLC-grade water. To each sample, $100 \mathrm{~mm}$ ammonium formate $(15 \mu \mathrm{l}, \mathrm{pH} 3.5)$ and $10 \mathrm{~mm}$ tetrabutylammonium chloride (TBAC) $(15 \mu \mathrm{l})$ were added. The mixture was extracted twice with water saturated 1-butanol. The combined organic phase was back-extracted twice with $250 \mu \mathrm{l} \times$ butanol saturated water to remove trace contaminants of normal nucleotides. The butanol extract was

\section{A}
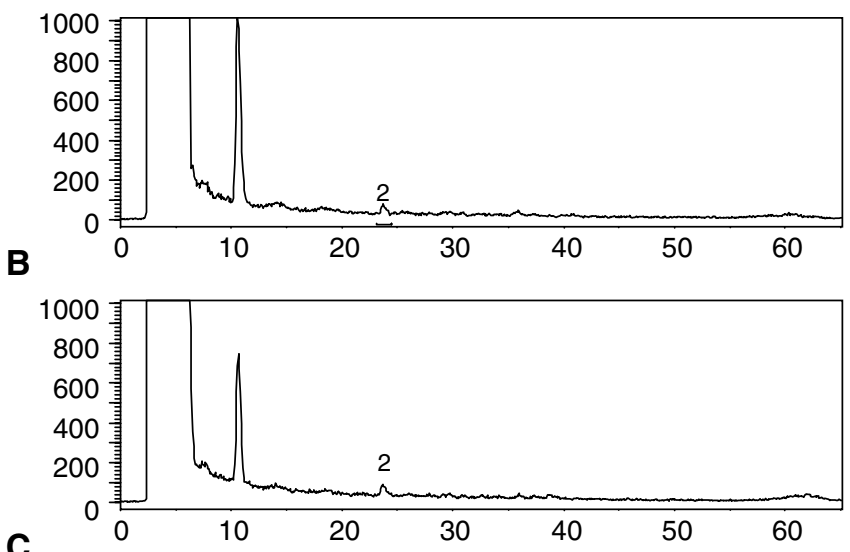

C
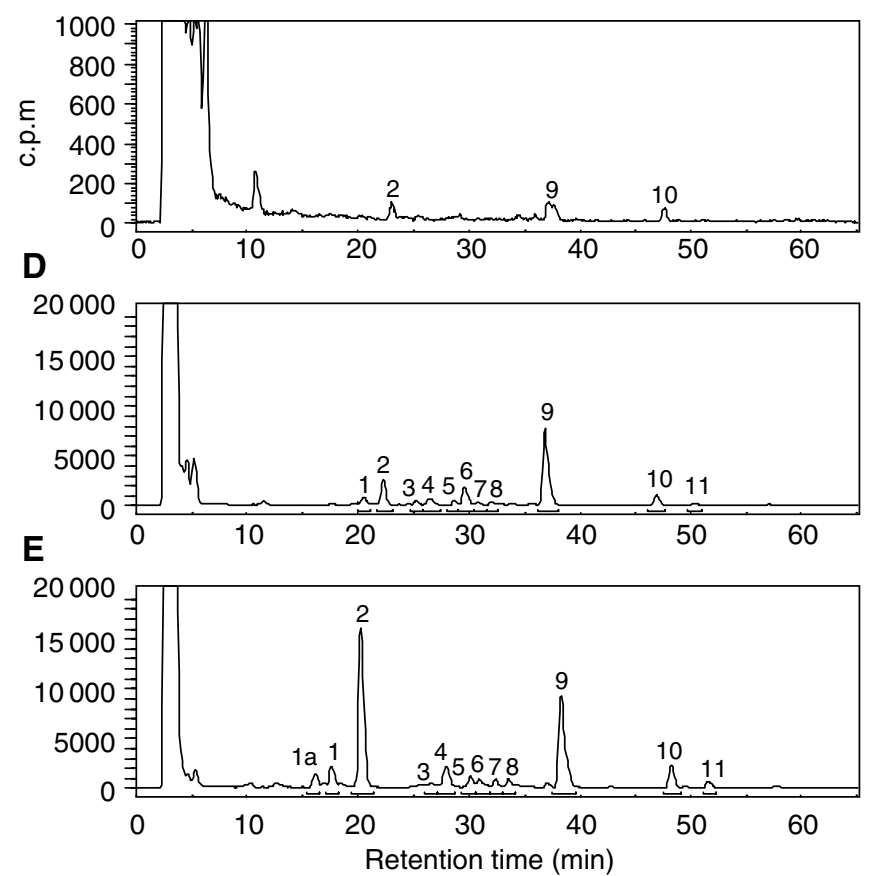

Figure 3 Radiochromatograms of ${ }^{32} \mathrm{P}$-postlabelled DNA adducts in DNA of MCF-7 cells following incubation with $(\mathbf{A})$ medium alone, $(\mathbf{B})$ $10 \mathrm{~nm},(\mathbf{C}) 100 \mathrm{~nm},(\mathbf{D}) \mid \mu \mathrm{M}$ and (E) $10 \mu \mathrm{M} 5 \mathrm{~F} 203$ for $72 \mathrm{~h}$. Adducts were enriched by butanol extraction prior to postlabelling and separated by HPLC. Note the $y$ scale of chromatograms for control, 10 and $100 \mathrm{~nm}$ is 1000 c.p.m. while the scale for 1 and $10 \mu \mathrm{M}$ is 20000 c.p.m. to aid resolution of the adduct profile. then neutralised by the addition of $3 \mu \mathrm{l} 200 \mathrm{~mm}$ Tris $\mathrm{HCl}$ $(\mathrm{pH}$ 7.6) and evaporated in a Speed Vac Concentrator (Savant Instruments, Inc., Hickville, NY, USA). Radiolabelling was achieved by incubating adducted nucleotides from $5 \mu \mathrm{g}$ DNA with T4 polynucleotide (6.25 units) and $62.5 \mu \mathrm{Ci}\left[\gamma^{32} \mathrm{P}\right] \mathrm{ATP}$ for $1 \mathrm{~h}$ at $37^{\circ} \mathrm{C}$.

The ${ }^{32} \mathrm{P}$-labelled products were diluted to $100 \mu \mathrm{l}$ with HPLCgrade water. The solution was injected onto a Hypersil ODS C18 analytical column $(250 \times 4.6 \mathrm{~mm}, 5 \mu \mathrm{M}$; Shandon $)$, eluted at a flow rate of $1.0 \mathrm{ml} \mathrm{min}^{-1}$ with $2 \mathrm{M}$ ammonium formate $(\mathrm{pH} 4.0)(\mathrm{A})$ and acetonitrile (B). HPLC gradient: $88 \%\left(\mathrm{vv}^{-1}\right)$ A initial mixture, $50 \mathrm{~min}$ linear gradient to $75 \% \mathrm{~A}$ followed by $15 \mathrm{~min}$ linear gradient to $55 \% \mathrm{~A}$. The radioactivity was monitored by a radiochemical detector (Lab Logic, $\beta$-RAM, Sheffield) lined to a Varian Star 9012 pump. Data analysis was by Laura (MS Windows package, Lab Logic Inc, Sheffield).

For quantification of the adduct levels, known amounts of $\left[\gamma_{-}{ }^{32} \mathrm{p}\right]$ ATP were injected onto the HPLC, peaks were collected and radioactivity was measured in disintegrations per min (dpm) by scintillation counting. ATP peak area was plotted against dpm to give a standard curve. For subsequent analyses, HPLC peak areas were measured and values were applied to this standard curve to give values in dpm. Relative adduct levels (RAL) were calculated according to Reddy and Randerath (1986) and translated into fmol adducts per $\mu \mathrm{g}$ DNA by multiplying RAL $\times 10^{7} \times 0.3240$ (Gupta, 1985). The specific activity of $\left[\gamma-{ }^{32} \mathrm{P}\right] \mathrm{ATP}$ was corrected by calculating the extent of decay.

Preliminary studies included enrichment of adducts by nuclease P1-catalysed dephosphorylation, exploiting the ability of certain bulky adducts to protect the nucleotide from digestion by nuclease $\mathrm{P} 1$ and the absolute requirement of the $3^{\prime}$ phosphate in the subsequent labelling step (transfer of $\gamma-{ }^{32} \mathrm{P}$ from ${ }^{32} \mathrm{P}$-ATP to the $5^{\prime}$ position of the nucleotides by the enzyme T4 polynucleotide kinase to give $3^{\prime}, 5^{\prime}$-bisphosphates). In addition to HPLC analyses, adducted DNA was separated by thin layer chromatography (TLC) in two directions on $10 \times 10 \mathrm{~cm}$ PEI-cellulose TLC plates. Samples were spotted in the lower left corner of each plate and run from top to bottom in $2.3 \mathrm{M}$ sodium phosphate, $\mathrm{pH}$ 5.8, onto an attached wick. After washing and drying, the plates were developed from bottom to top in $2.79 \mathrm{M}$ lithium formate, $4.95 \mathrm{~m}$ urea, $\mathrm{pH}$ 3.4. The final chromatographic washes were run at $90^{\circ}$ (left to right) in $0.75 \mathrm{M}$ sodium dihydrogenhosphate, $0.45 \mathrm{M}$ Tris, $8.0 \mathrm{M}$ urea, $\mathrm{pH} 8.2$ and then $1.7 \mathrm{M}$ sodium phosphate, $\mathrm{pH} 6.0$ onto an attached wick.

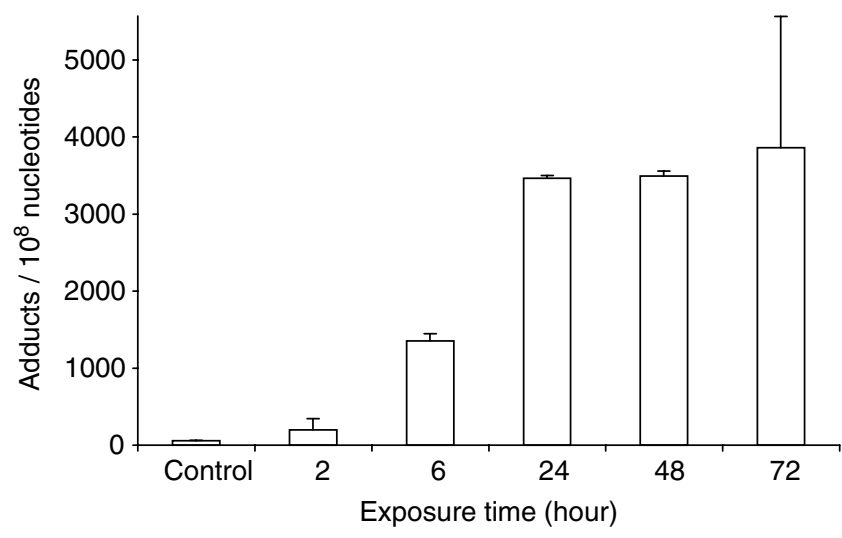

Figure 4 Accumulation of DNA adducts in MCF-7 cells in vitro, treated with I $\mu \mathrm{M}$ 5F 203. Following extraction of DNA, adducts were enriched by butanol extraction, ${ }^{32}$ P-postlabelled and separated by HPLC. Bars, s.d. $(n \geqslant 3)$. 


\section{RESULTS}

\section{In vitro}

Preliminary studies clearly demonstrated DNA adduct formation in sensitive cells only (e.g. MCF-7, MDA 468 human mammary carcinoma cell lines) following their exposure to DF 203, irrespective of the analytical method adopted (Stevens et al, 2001). Enrichment of adducts by butanol extraction or nuclease P1 digestion prior to adduct separation by TLC (Figure 2) or HPLC unequivocally demonstrated the formation of one major and a number of minor adducts in the DNA of MCF-7 cells after drug treatment ( $1 \mu \mathrm{M}$ DF 203, $72 \mathrm{~h})$. Insensitive HCT 116 cells incurred negligible DNA damage. The chromatographic profile of DNA adducts in MDA 468 cells was identical to that generated in MCF-7 cells (result not shown). No adducts were detected in HPLC traces of untreated cells.

It was concluded that butanol extraction prior to quantitative HPLC separation of benzothiazole-derived adducts was the protocol most suitable for their detection using the ${ }^{32} \mathrm{P}$-postlabelling technique.
A

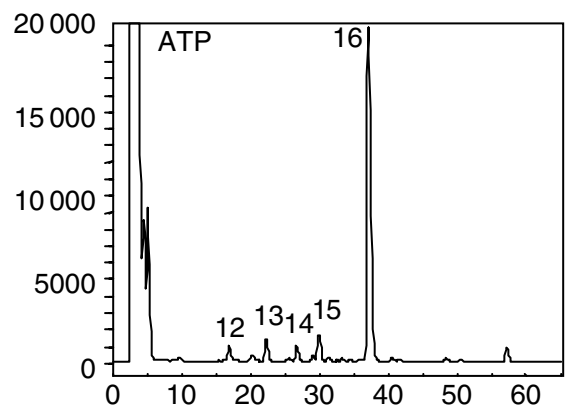

C

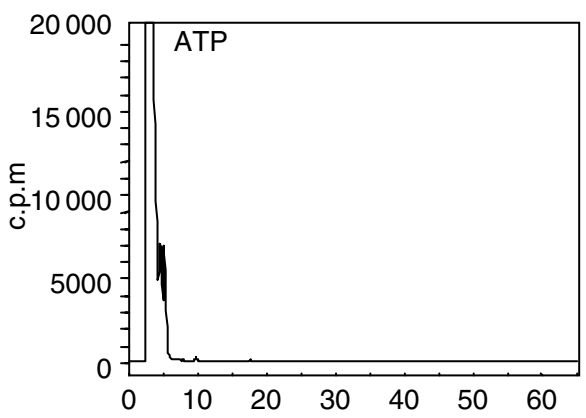

E

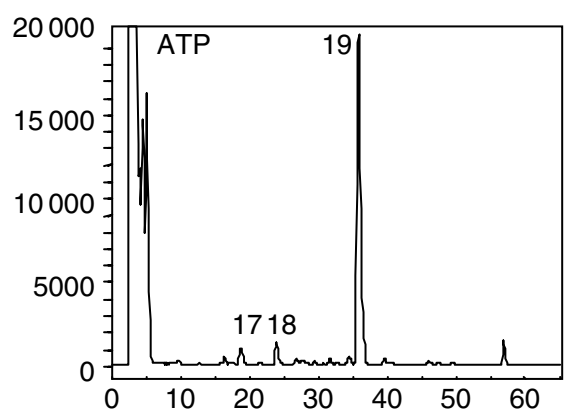

\section{F 203 dose response}

MCF-7 mammary carcinoma cells were exposed to concentrations of $5 \mathrm{~F} 203$ between $10 \mathrm{~nm}$ and $10 \mu \mathrm{m}$ for $72 \mathrm{~h}$ before DNA was extracted, adducted nucleotides enriched and adduct levels determined by HPLC (Figure 3). Following exposure of cells to $10 \mathrm{~nm} 5 \mathrm{~F} 203$, very few adducts were detected. 5F 203-derived DNA adducts (labelled 2, 9 and 10) were separated after treatment of cells with $100 \mathrm{~nm}$ drug. $1 \mu \mathrm{M}$ 5F 203 effected considerable adduct formation; 1 major adduct, 9, and a number of minor adducts (e.g. represented by peaks 2 and 10) were evident. Following treatment of cells with $10 \mu \mathrm{M} 5 \mathrm{~F} 203$, the total number of adducts increased; strikingly, the major adduct had become adduct 2 (Figure 3E). Adducts (represented by peak 9) increased only slightly.

\section{Accumulation of DNA adducts with time}

After only $2 \mathrm{~h}$ treatment ( $1 \mu \mathrm{M} 5 \mathrm{~F} 203$ ) adducts could be detected in the DNA of MCF-7 cells. Accumulation of DNA adducts was evident up to $24 \mathrm{~h}$ exposure, at which point potential for further adduct formation appeared saturated (Figure 4).

\section{B}

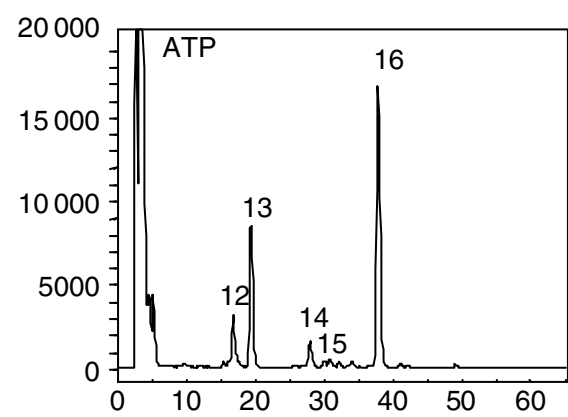

D

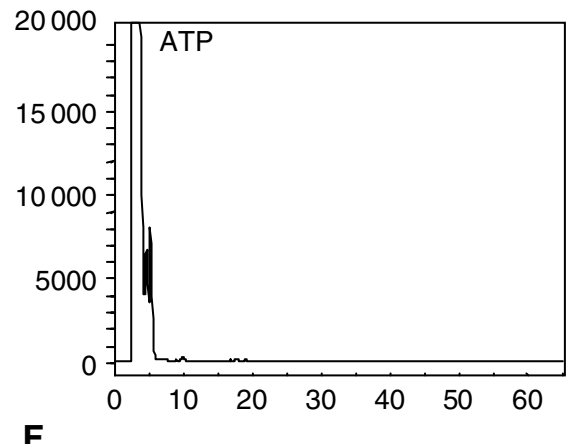

$\mathbf{F}$

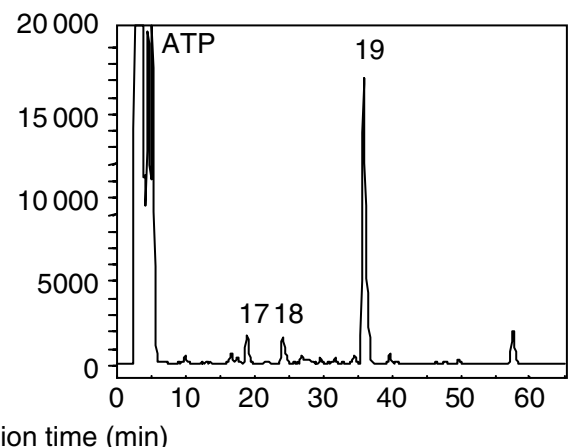

Figure 5 HPLC separation of butanol-extracted, ${ }^{32}$ P-postlabelled DNA adducts in MCF-7 (A and B), MDA-MB-435 (C and D) and IGROV-I (E and F) cells following exposure to I $\mu \mathrm{M}(\mathbf{A}, \mathbf{C}$ and $\mathbf{E})$ and $10 \mu \mathrm{M}$ Phortress (B, D and $\mathbf{F})$ in vitro. MCF-7 and MDA-MB-435 cells were exposed to drug for $72 \mathrm{~h}$. DNA adducts generated in IGROV-I cells were analysed after $24 \mathrm{~h}$ treatment. 
Selective generation of Phortress-derived DNA adducts in vitro

Adducts were detected in the DNA of MCF-7 and IGROV-1 cells exposed to concentrations of Phortress $\geqslant 100 \mathrm{nM}$ : $1 \mu \mathrm{M}$ Phortress induced one major and a number of minor adducts (Figure 5). However, adduct profiles in these two cell lines were not identical: peaks equivalent to adducts 14 and 15 in the DNA of MCF-7 cells were absent in DNA extracted from IGROV-1 cells exposed to $1 \mu \mathrm{M}$ Phortress. MCF-7 cells received $72 \mathrm{~h}$ Phortress exposure, whereas after this length of time Phortress was lethal to IGROV-1 cells. Thus, DNA adduct accumulation was analysed in IGROV-1 cells after $24 \mathrm{~h}$ exposure to Phortress. The profile and number of DNA adducts in DNA isolated from IGROV-1 cells do not differ significantly whether exposed to 1 or $10 \mu \mathrm{M}$ Phortress. However, following treatment of MCF-7 cells with $10 \mu \mathrm{M}$ Phortress, a new major adduct emerged (peak 13). Significantly, the DNA of MDAMB-435 cells treated with Phortress $(72 \mathrm{~h}, 10 \mathrm{nM}-10 \mu \mathrm{M})$ remained free from Phortress-derived adducts.

\section{Generation of Phortress-derived DNA adducts in vivo}

Mice bearing sensitive MCF-7, IGROV-1 and inherently resistant MDA-MB-435 tumours s.c. in the flank were treated with
$20 \mathrm{mg} \mathrm{kg}^{-1}$ Phortress or vehicle alone (i.p.). Guided by in vitro data (Figure 4) and the knowledge that CYP1A1 protein can clearly be detected within sensitive xenografts $24 \mathrm{~h}$ post-treatment (Bradshaw et al, 2002a), tumours were recovered $24 \mathrm{~h}$ after animals were treated and DNA extracted. HPLC detection of ${ }^{32} \mathrm{P}$ postlabelled adducts clearly distinguished one major and a number of minor Phortress-derived adducts in the DNA of MCF-7 xenografts (Figure 6). As the technique is quantitative, it can be seen that the number and diversity of adducts sustained in IGROV-1 tumours is significantly less than the number of Phortress-derived DNA adducts detected in MCF-7 xenografts. No adducts were detected in MDA-MB-435 DNA.

Data shown in Figure 7 demonstrate that Phortress-derived adducts in vivo co-chromatograph with adducts formed by 5F 203 in vitro. The retention time of the major adduct detected in MCF-7 tumours of Phortress-treated mice was identical to that seen following treatment of MCF-7 cells in vitro with $5 \mathrm{~F} 203$. Adducts 20, 21 and 22 formed in MCF-7 xenografts of mice treated with a single dose of $20 \mathrm{mg} \mathrm{kg}^{-1}$ Phortress $(24 \mathrm{~h})$ were found to coelute with adducts 2, 6 and 9 derived from MCF-7 cells exposed to $1 \mu \mathrm{M}$ 5F 203 (72h).

Mice bearing sensitive MCF-7 tumours in one flank and inherently resistant MDA-MB-435 tumours in the opposite flank$$
\text { A }
$$
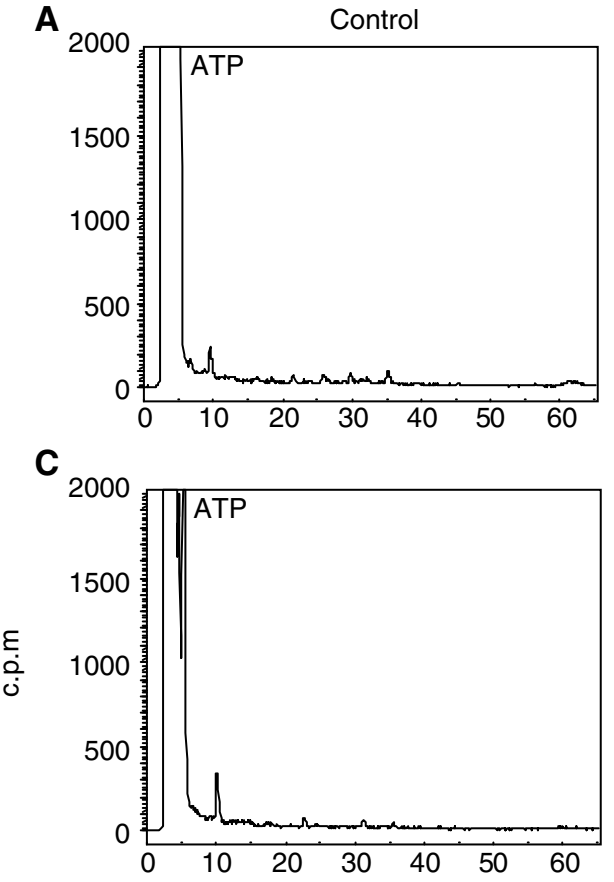

E

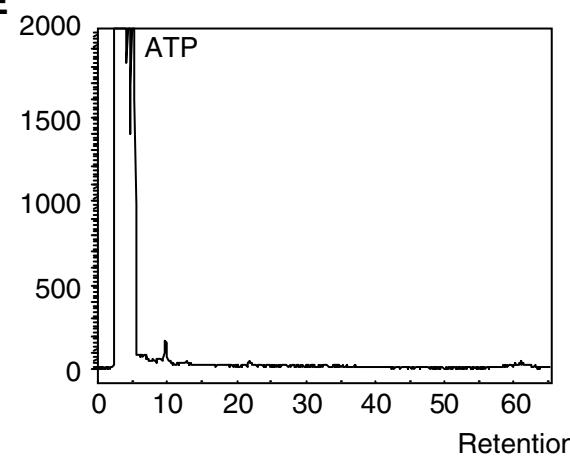

B

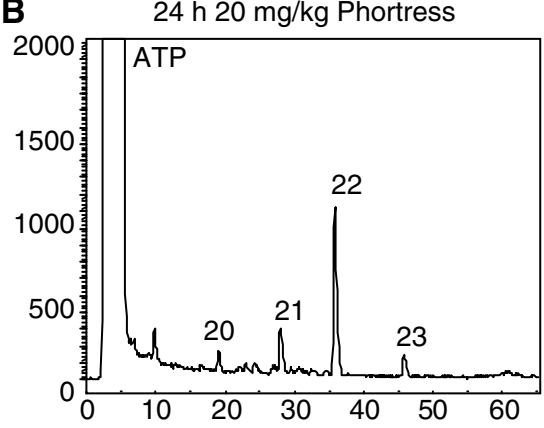

D

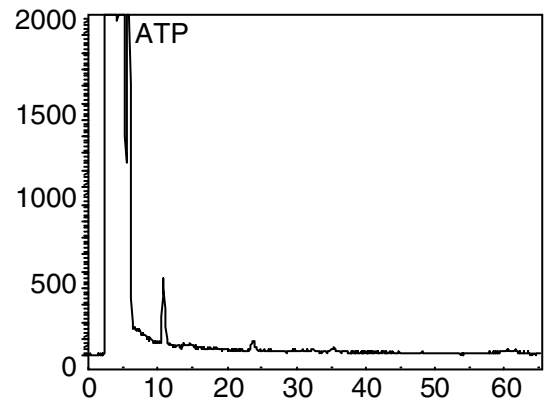

$\mathbf{F}$

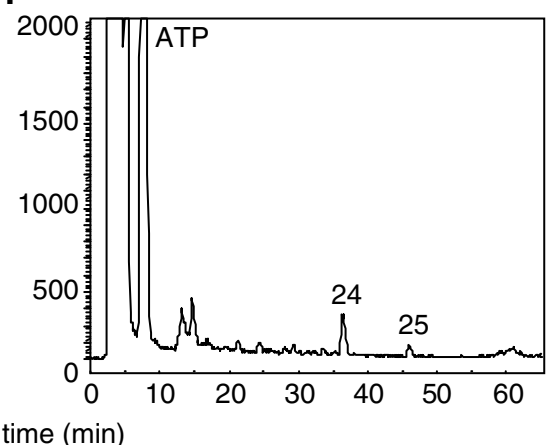

Figure 6 HPLC separation of ${ }^{32} \mathrm{P}$-postlabelled adducts of control MCF-7 (A), MDA-MB-435 (C) and IGROV-I (E) xenografts from untreated animals and MCF-7 (B), MDA-MB-435 (D) and IGROV-I (F) xenografts from mice treated with $20 \mathrm{mg} \mathrm{kg}^{-1}$ Phortress i.p. Tumours were recovered $24 \mathrm{~h}$ posttreatment. 
A

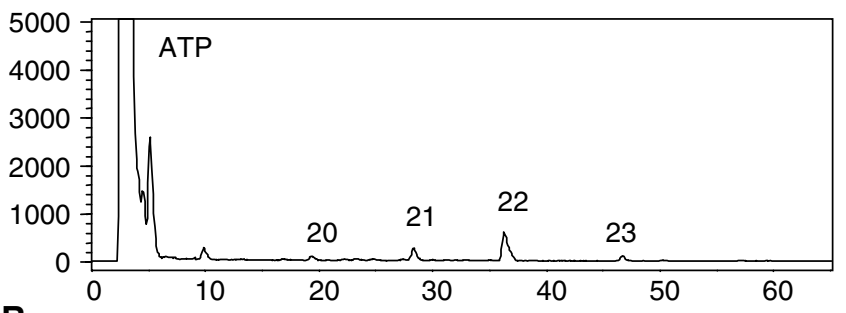

B
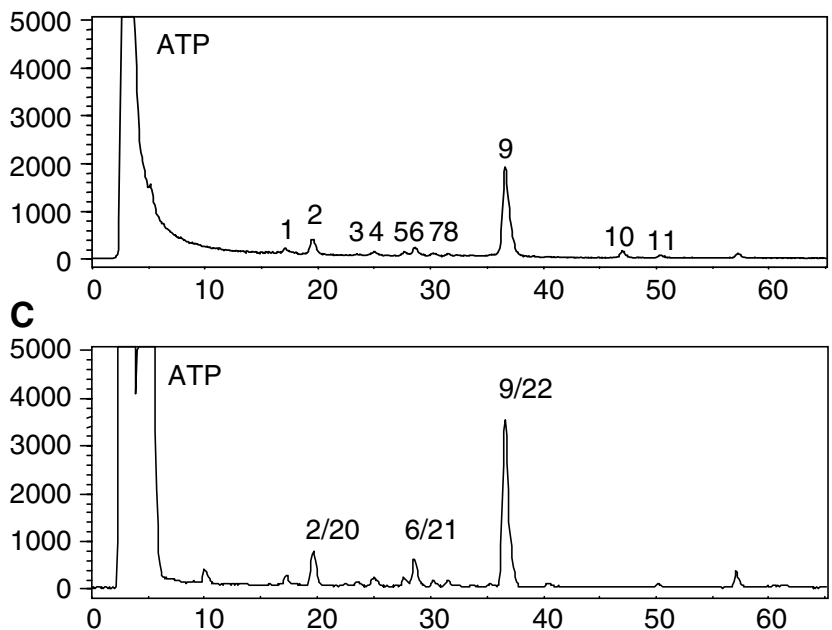

Figure 7 HPLC radiochromatograms of ${ }^{32} \mathrm{P}$-postlabelled adducts. (A) DNA $(5 \mu \mathrm{g})$ from MCF-7 xenograft of Phortress-treated $\left(20 \mathrm{mg} \mathrm{kg}^{-1}\right.$, i.p.) mouse. (B) DNA $(0.5 \mu \mathrm{g})$ from MCF-7 cells treated with I $\mu \mathrm{M} 5 \mathrm{~F} 203$ for 72 h. (C) Coelution of $\mathbf{A}$ and $\mathbf{B}$.

were treated i.p. with $20 \mathrm{mg} \mathrm{kg}^{-1}$ Phortress. After $24 \mathrm{~h}$, animals were killed and tumours were prepared for analysis of DNA adducts. The specificity for DNA adduct formation in sensitive tumours only is unequivocally observed (Figure 8). Numbers of adducts detected in MCF-7 xenografts did not differ significantly from those previously detected $\left(260 \pm 80 \times 10^{-8}\right.$ nucleotides $)$.

\section{DISCUSSION}

In this study, we have examined the hypothesis that DNA adduct formation may be the biochemical sequel to CYP-mediated metabolic production of putative electrophilic species derived from antitumour 2-(4-aminophenyl)benzothiazoles. It is proposed that the generation of covalent adducts in sensitive cells precedes

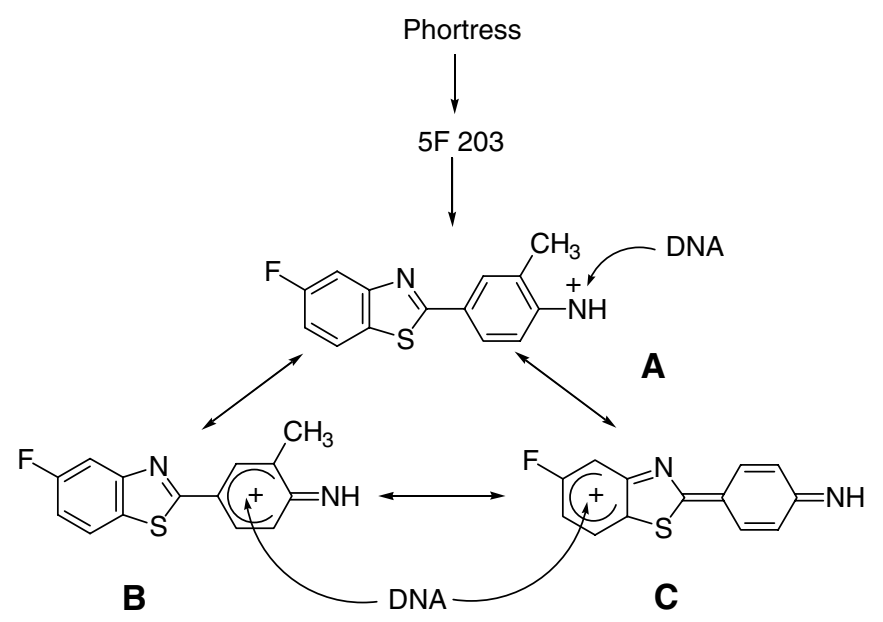

Figure 9 Putative electrophilic reactive intermediates derived from Phortress. Species A is a nitrenium ion. Species B and C are $\pi$-carbocation mesomeric forms.

the exquisitely selective cell death ensuing exposure, in vitro and in vivo, to analogues of this distinct class of antitumour agent. In vitro, sensitivity correlates with induction of CYP1A1 mRNA, activity and protein expression. Engagement of apoptotic machinery (induction of apoptosis-initiating receptor CD95/FAS1, upregulation of P53 and P21, downregulation of Bcl-2; Monks et al, 2001; Chua et al, 1999a,b) and detection of DNA single-strand breaks has been observed in responsive mammary carcinoma cells when challenged with benzothiazole analogues (Bradshaw et al, 2000).

Selective generation of DNA adducts in cell lines (MCF-7, IGROV-1) sensitive to 2-(4-aminophenyl)benzothiazole analogues (DF 203, 5F 203, Phortress) has been demonstrated, whereas negligible adduct formation was detected in DNA of inherently resistant HCT 116 colon (Figure 2) and MDA-MB-435 breast carcinoma cells.

Few adducts could be detected in the DNA of sensitive (MCF-7, IGROV-1) cells exposed to concentrations of 5F 203 or Phortress $<100 \mathrm{~nm}$. Evidence supports the supposition that DNA repair mechanisms are employed: human damage-specific DNA-binding protein (DDB) mRNA is significantly upregulated in sensitive MCF-7 cells after benzothiazole treatment. DDB, a heterodimer of 48 and $127 \mathrm{kDa}$ subunits, possesses a role in DNA repair and is upregulated in response to UV-induced lesions (Nichols et al, 2000). Moreover, DDB activity is absent from a subset of xeroderma pigmentosum (XP) patients possessing a phenotype of defective excision repair (Zolezzi and Linn, 2000). In addition
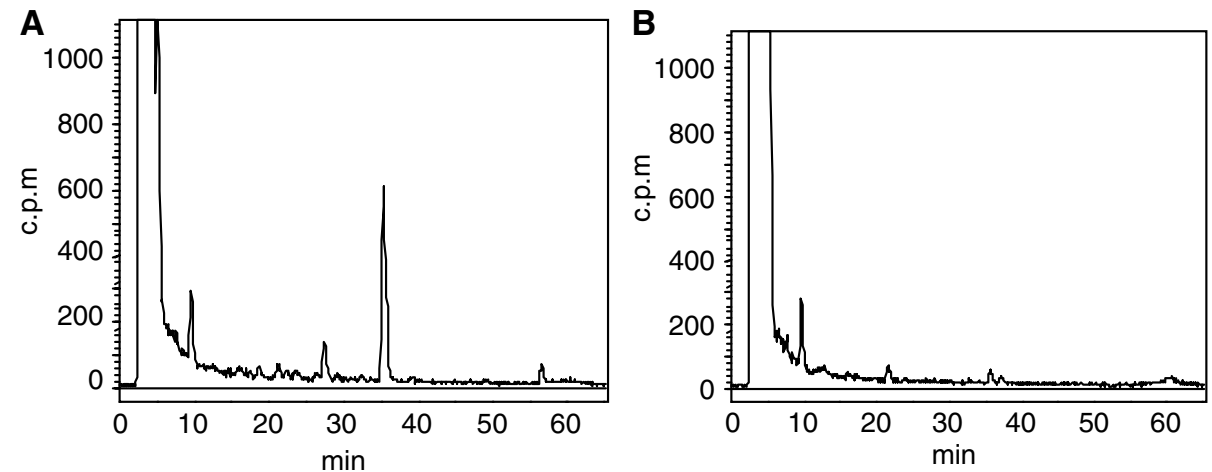

Figure 8 Analysis of DNA adduct formation in tumour xenografts implanted s.c. in opposite flanks of the same mouse recovered $24 \mathrm{~h}$ after Phortress treatment $\left(20 \mathrm{mg} \mathrm{kg}^{-1}\right.$, i.p.). (A) MCF-7. (B) MDA-MB-435. 
Wip1, a human protein phosphatase induced in response to ionising radiation (Fiscella et al, 1997), is also upregulated following benzothiazole treatment. Alternatively, nucleophilic sequestration of low concentrations of reactive intermediates by cellular peptides (e.g. glutathione) or proteins may occur at low drug concentrations. At $1 \mu \mathrm{M}$ 5F 203 a clear adduct profile emerges in DNA of MCF-7 cells revealing one major and a number of minor adducts. Intriguingly, and emphatically at $10 \mu \mathrm{M}$, a new major adduct, 2, dominates. In MCF-7 cells treated with $10 \mu \mathrm{M}$ Phortess, the previously minor peak 13, analogous to the 5F 203-generated peak 2, becomes an emerging major adduct. This phenomenon fails to occur in IGROV-1 cells whose capacity for adduct burden appears saturated at $1 \mu \mathrm{m}$. We may speculate that CYP1A1 and CYP1B1 effect the formation of distinct 5F 203-derived adducts and moreover that CYP1A1- and CYP1B1-induced adducts are generated by exposure to different benzothiazole concentrations. In IGROV-1 cells, CYP1B1 protein expression was not constitutive and only negligibly induced by $5 \mathrm{~F} 203(1 \mu \mathrm{M}, 10 \mu \mathrm{M})$ (Hose et al, in press). In MCF-7 cells, constitutively expressed CYP1B1 is further induced by 2 -(4-aminophenyl)benzothiazole concentrations exceeding $3 \mu \mathrm{m}$ concurring with the emergence of major adduct $2(5 \mathrm{~F}$ 203 ) or 13 (Phortress). EROD activity and CYP1A1 expression are maximally induced in cells treated with $1 \mu \mathrm{M} \mathrm{2-(4-aminophenyl)-}$ benzothiazoles concurring with the apparent saturation of adduct 9 (5F 203, MCF-7 cells), 16 (Phortress, MCF-7 cells) or 19 (Phortress, IGROV-1 cells). Indeed, concentrations $>1 \mu \mathrm{M}$ result in irreversible inhibition of CYP1A1 activity (Chua et al, 2000).

In V79 cells stably expressing either CYP1A1 or CYP1B1 enzymes, significantly lower concentrations of dibenzo $[a, l]$ pyrene are required before the formation of the highly carcinogenic CYP1B1-dependent (-)-anti-dibenzo[ $[a, l]$ pyrene diol epoxide (DB $[a, l] \mathrm{PDE})$ adducts (Luch et al, 1998). In addition, CYP regioselectivity towards the endogenous hormone $17 \beta$-oestradiol has been demonstrated; 1A1 catalyses 2-hydroxylation, whereas CYP1B1 is a highly selective oestradiol 4-hydroxylase.

Generation of 5F 203-derived adducts over time (Figure 4) correlated precisely with induction of CYP1A1 transcription and EROD activity in MCF-7 cells treated with 2-(4-amino-3-methylphenyl)benzothiazoles. In vitro, adduct accumulation occurred maximally by $24 \mathrm{~h}$.

Significant DNA adducts were detected in MCF-7 tumour xenografts $24 \mathrm{~h}$ after treatment of mice with a concentration of Phortress known to elicit antitumour activity (Bradshaw et al, 2002a). Phortress $\left(2 \times 20 \mathrm{mg} \mathrm{kg}^{-1}\right.$, i.p. $)$, administered weekly, inhibited the growth of these tumours by $68 \%\left(\mathrm{vv}^{-1}\right)$. In IGROV-1 tumours of treated mice, where Phortress administered on the same schedule inhibited xenograft growth by $50 \%$, fewer DNA adduct species were separated; moreover, adducts, whose profile was chromatographically equivalent to that of MCF-7 tumours, were significantly fewer (Figure 6). Negligible adducts were generated in inherently resistant MDA-MB-435 tumours. Thus, adduct burden concurs exactly with the sensitivities of these three xenografts to Phortress. We suggest that in human IGROV-1 xenografts, the major Phortress-derived DNA adduct 24 is equivalent to adduct 22 in MCF-7 tumours. In vitro, equivalent Phortress-generated adduct species are represented by peaks 16 and 19 in MCF-7 and IGROV-1 cells, respectively. In MCF-7 cells, Phortress-derived adducts represented by peaks 13 and 16 (Figure 5) are equivalent to 5F 203-generated adducts 2 and 9
(Figure 3). Evidence confirming that a major adduct is commonly induced in vitro and in vivo by 5F 203 and its lysylamide prodrug has been obtained. DNA extracted from MCF-7 cells exposed to $5 \mathrm{~F}$ $203(1 \mu \mathrm{M}$, peak 9) and MCF-7 xenograft tissue of a mouse exposed to Phortress (peak 22) coelute, demonstrating the generation of identical adduct species.

The exquisite specificity of Phortress-derived adduct generation has been corroborated, following treatment of mice bearing sensitive MCF-7 and inherently resistant MDA-MB-435 tumours in opposite flanks (Figure 8). Thus, tumour sensitivity has been predicted accurately: in antitumour tests, the growth of MCF-7 xenografts was significantly retarded whereas MDA-MB-435 tumours transplanted in the opposite flank continued to grow (Bradshaw et al, 2002a). Thus, we propose that the evaluation of DNA adduct formation may provide a valuable pharmacodynamic (PD) end point predictive of tumour sensitivity.

Phortress effects an exquisitely selective antitumour response via a mechanism of action distinct from any clinically used chemotherapeutic agent. It is cleaved in the presence of tumour cells to yield $5 \mathrm{~F} 203$, which remains inertly in the milieu of cells immune to this agent. However, once in the presence of a sensitive cancer cell, a cascade of events is initiated resulting in the induction of CYP1A1-catalysed metabolism of 5F 203. Generation of adducts between electrophilic reactive intermediates of 5F 203 and DNA exacts lethal damage that precedes cell death.

FMO calculations predict that a reactive electrophilic nitrenium species may be implicated in the generation of DNA adducts (O'Brien et al, in press). Structures of a nitrenium species and $\pi$-carbocation mesomeric forms derived from $5 \mathrm{~F} 203$ are shown in Figure 9. These structures infer that nucleophilic centres in DNA bases might become adducted at the exocyclic nitrogen (via A), or at carbon atoms in the 2-aryl group (B) or the benzothiazole moiety (C; Stevens et al, 1996). This could explain the multiplicity of adducts observed in sensitive tumour cells such as MCF-7 (Figure $3 \mathrm{E}$ ). We are currently attempting to identify the structures of these adducts to determine why they are so damaging to sensitive tumour cells.

In conclusion, Phortress offers the opportunity for introduction into the clinic of a novel and selective antitumour agent. The techniques described present potential for the measurement of a clearly defined PD end point.

Phortress will undergo clinical evaluation under the auspices of Cancer Research UK and Phase I trials are due to begin in 2003.

\section{ACKNOWLEDGEMENTS}

We thank Cancer Research UK for support to the Experimental Cancer Chemotherapy Research Group, Nottingham, and the Cancer Research Unit, Bradford. We gratefully acknowledge extensive collaborations, support and discussions with the members of the Developmental Therapeutics Program of the NCI and the Screening and Pharmacology Group within the European Organisation for Research and Treatment of Cancer (EORTC).

This study was supported by the Cancer Research UK and the National Cancer Institute, USA. This is part 22 in the series 'Antitumour benzothiazoles'.

\section{REFERENCES}

Bradshaw TD, Bibby MC, Double JA, Fichtner I, Cooper PA, Alley MC, Donahue S, Tomaszewjski JE, Sausville EA, Stevens MFG (2002a) Preclinical evaluation of amino acid prodrugs of novel antitumor 2-(4amino-3-methylphenyl)benzothiazoles. Mol Cancer Ther 1: 239-246
Bradshaw TD, Chua M-S, Browne HL, Trapani V, Sausville EA, Stevens MFG (2002b) In vitro evaluation of amino acid prodrugs of novel antitumour 2-(4-amino-3-methylphenyl)benzothiazoles. $\mathrm{Br}$ J Cancer 86: $1348-1354$ 
Bradshaw TD, Chua M-S, Orr S, Matthews CS, Stevens MFG (2000) Mechanisms of acquired resistance to 2-(4-aminophenyl)benzothiazole (CJM 126, NSC 34445). Br J Cancer 83: 270-277

Bradshaw TD, Shi D-F, Schultz RJ, Paull KD, Kelland L, Wilson A, Garner C, Fiebig HH, Wrigley S, Stevens MFG (1998b) Influence of 2-(4aminophenyl)benzothiazoles on growth of human ovarian carcinoma cells in vitro and in vivo. Br J Cancer 78: 421-429

Bradshaw TD, Wrigley S, Shi D-F, Schultz RJ, Paull KD, Stevens MFG (1998a) 2-(4-Aminophenyl)benzothiazoles: novel agents with selective profiles of antitumour activity. Br J Cancer 77: 745-752

Chua M-S, Bradshaw TD, Stevens MFG (1999a) 2-(4-Aminophenyl)benzothiazoles: agents with selective and potent antitumour activity in vitro and in vivo. In Relevance of Tumour Models for Anticancer Drug Development, Fiebig HH, Burger AM (eds) Vol. 54. Contrib Oncol Basel pp 397-408. Basel: Karger

Chua M-S, Kashiyama E, Bradshaw TD, Stinson S, Brantley E, Sausville EA, Stevens MFG (2000) Role of CYP1A1 in modulation of antitumour properties of the novel agent 2-(4-amino-3-methylphenyl)benzothiazole (DF 203, NSC 674495) in human breast cancer cells. Cancer Res 60: $5196-5203$

Chua M-S, Shi D-F, Wrigley S, Bradshaw TD, Hutchinson I, Shaw PN, Barrett DA, Stanley LA, Stevens MFG (1999b) Antitumour benzothiazoles. 7. Synthesis of 2-(4-acylaminophenyl)benzothiazoles and investigations into the role of acetylation in the antitumour activities of the parent amines. J Med Chem 42: 381-392

Crofts FG, Sutter TR, Strickland PT (1998) Metabolism of 2-amino-1methyl-6-phenylimidazo[4,5-b]pyridine by human cytochrome P4501A1, P4501A2 and P4501B1. Carcinogenesis (London) 19: 1969-1973

Fiscella M, Zhang HL, Fan S, Sakaguchi K, Shen S, Mercer WE, VandeWoude GF, O'Connor PM, Apella E (1997) Wip1, a novel human protein phosphatase that is induced in response to ionising radiation in a p53-dependent manner. Proc Natl Acad Sci USA 94: 6048-6053

Guengerich FP (1992) The Bernard B Brodie award lecture: bioactivation and detoxification of toxic and carcinogenic chemicals. Drug Metab Dispos 21: 1-6

Gupta RC (1985) Enhanced sensitivity of ${ }^{32}$ P-postlabeling analysis of aromatic carcinogen-DNA adducts. Cancer Res 45: 5656-5662

Hose C, Holligshead M, Sausville E, Monks A (in press) Induction of CYP1A1 in tumour cells by the antitumour agent 2-(4-amino-3methylphenyl)-5-fluorobenzothiazole: a potent surrogate marker for patient sensitivity. Cancer Research

Hutchinson I, Chua M-S, Browne HL, Trapani V, Bradshaw TD, Westwell AD, Stevens MFG (2001) Antitumour benzothiazoles. 14. Synthesis and in vitro biological properties of fluorinated 2-(4-aminophenyl)benzothiazoles. J Med Chem 44: 1446-1455

Hutchinson I, Jennings SA, Vishnuvajjala BR, Westwell AD, Stevens MFG (2002) Antitumour benzothiazoles. 16. Synthesis and pharmaceutical properties of antitumour 2-(4-aminophenyl)benzothiazole amino acid prodrugs. J Med Chem 45: 744-747

Kashiyama E, Hutchinson I, Chua M-S, Stinson S, Phillips LR, Kaur G, Sausville EA, Bradshaw TD, Westwell AD, Stevens MFG (1999) Antitumour benzothiazoles. 8. Synthesis, metabolic formation, and biological properties of $\mathrm{C}$ - and $\mathrm{N}$-oxidation products of 2-(4-aminophenyl)benzothiazoles. J Med Chem 42: 4172-4184
Loaiza-Perez AI, Trapani V, Hose C, Singh SS, Trepel J, Stevens MFG, Bradshaw TD, Sausville EA (2002) The AhR mediates sensitivity of MCF7 breast cancer cells to the antitumour agent 2-(4-amino-3-methylphenyl)benzothiazole. Mol Pharmacol 61: 13-19

Luch A, Coffing SL, Tang YM, Schneider A, Soballa V, Greim H, Jefcoate CR, Seidel A, Greenlee WF, Baird WM, Doehmer J (1998) Stable expression of human cytochrome P450 1B1 in V79 Chinese hamster cells and metabolically catalysed DNA adduct formation of dibenzo[a,l]pyrene. Chem Res Toxicol 11: 686-695

Martin EA, Carthew P, White INH, Heydon RT, Gaskell M, Mauthe RJ, Turtletaub KW, Smith LL (1997) Investigation of the formation and accumulation of liver DNA adducts in mice chronically exposed to tamoxifen. Carcinogenesis 18: 2209-2215

Martin EA, Heydon RT, Brown K, Brown JE, Lim C-K, White INH, Smith LL (1998) Evaluation of tamoxifen and $\alpha$-hydroxytamoxifen ${ }^{32} \mathrm{P}$-postlabelled DNA adducts by the development of a novel automated online solid-phase extraction HPLC method. Carcinogenesis 19: 1061-1069

Monks A, Rivera MI, Harris E, Hose C, Sausville EA (2001) Gene expression changes induced by a novel antitumour agent, 2-(4-amino-3-methylphenyl)benzothiazole, in MCF-7, a sensitive breast cancer cell line, using cDNA microarrays. Proc Am Assoc Cancer Res 42 (3417): 635

Nichols AF, Itoh T, Graham JA, Liu W, Yamaizumi M (2000) Human damage-specific DNA-binding protein p48: characterization of XPE mutations and regulation following UV irradiation. J Biol Chem 275: $21422-21428$

O'Brien S, Browne HL, Bradshaw TD, Westwell AD, Laughton CA, Stevens MFG (in press) Antitumour benzothiazoles. Cytochrome P $4501 \mathrm{~A} 1$ mediated activation of fluorinated 2-(4-aminophenyl)benzothiazoles: frontier molecular orbital methods rationalise and predict metabolites. Org Biomol Chem

Reddy MV, Randerath K (1986) Nuclease P1-mediated enhancement of sensitivity of ${ }^{32} \mathrm{P}$-postlabeling test for structurally diverse DNA adducts. Carcinogenesis 7: $1543-1551$

Shi D-F, Bradshaw TD, Wrigley S, McCall CJ, Lelieveld P, Stevens MFG (1996) Antitumour benzothiazoles 3 Synthesis of 2-(4-aminophenyl)benzothiazoles and evaluation of their activities against breast cancer cell lines in vitro and in vivo. J Med Chem 39: 3375-3384

Shimada T, Hayes CL, Yamazaki H, Amin S, Hecht SS, Guengerich P, Sutter TR (1996) Activation of chemically diverse procarcinogens by human cytochrome P-450 1B1. Cancer Res 56: 2979-2984

Shimada T, Wunsch RM, Hanna IH, Sutter TR, Guengerich FP, Gillam EMJ (1998) Recombinant human cytochrome P450 1B1 expression in Escherichia coli. Arch Biochem Biophys 357: 111-120

Stevens MFG, Heydon RT, Martin EA, Farmer PF, Bradshaw TD, Hutchinson I, Westwell AD, Browne HL, Trapani V (2001) Induction of CYP1A1 by 2-(4-aminophenyl)benzothiazoles leads to DNA adducts in sensitive tumour cells. Proc Amer Assoc Cancer Res 42 (1754): 325

Stevens MFG, Shi D-F, Castro A (1996) Antitumour benzothiazoles. Part 2. Formation of 2,2'-diaminobiphenyls from the decomposition of 2-(4azidophenyl)benzazoles in trifluoromethanesulfonic acid. J Chem Soc Perkin Trans 1: 83-93

Zolezzi F, Linn S (2000) Studies of the murine DDB1 and DDB2 genes. Gene 245: $51-150$ 